\title{
Effect of Chemical Thinning Sprays on Apple Fruit Set
}

\author{
R.E. Byers ${ }^{1}$ and \\ D.H. Carbaugh ${ }^{2}$
}

Additional index words. Malus

domestica, pesticides, photosynthesis

Summary. Apple growers of different regions need different chemical fruitthinning responses for thinning trees of different tree ages, cultural conditions, rootstocks, climates, and amounts of fruit removal desired. In this research, a range of chemical thinning responses was achieved by combinations of thinning materials or addition of potentiating agents. Superior oil, certain organic phosphates, and a light-absorbing agent (ferbam, a fungicide) increased the thinning of carbaryl. In addition, combinations of 50 or $200 \mathrm{ml}$ 6-BA/ liter + carbaryl + oil defruited 'Campbell Redchief Delicious'/ M.111 trees, and $50 \mathrm{ml}$ 6-BA/liter alone over-thinned in one year (however, oil or 6-BA has been shown previously to cause russet in 'Golden Delicious'). Carbaryl 50 WP and the $4 \mathrm{~L}$ carbaryl formulations were equally effective for thinning 'Golden Delicious', 'Stayman', and 'Redspur Delicious', and did not affect fruit russet. Three days of cloudy weather is typical at least once in most seasons in the eastern United States during the fruit set period. Two days of artificial polypropylene shading $(92 \%)$ (which was nearly equivalent to 3 days of cloudy weather) caused more thinning of 'Golden Delicious' and 'Stayman' than carbaryl or $10 \mathrm{mg}$ NAA/liter + Tween. Shading reduced viable seed numbers about $50 \%$ for 'Golden Delicious' in fruit remaining at harvest, but chemical thinning agents (NAA or carbaryl) did not affect viable seed number.

'Professor of Horticulture.

${ }^{2}$ Agriculisural Manager.

Department of Horticulture, Agricultural Experiment Station, Virginia Polytechnic Institute and State University, Winchester, VA 22601. 
Y pur 'Delicious' strains of apple normally set heavy crops and are $\checkmark$ difficult to thin adequately with carbaryl (Herrera-Aguirre and Unrath, 1980; Rogers and Williams, 1977). The effectiveness of carbaryl was increased by the addition of superior spray oil (Byers, 1978; Byers et al., 1982). Rates of naphthaleneacetic acid (NAA) above $5 \mathrm{mg} \cdot$ liter $^{-1}$ or napthaleneacetamide (NAD) at $50 \mathrm{mg} \cdot$ liter $^{-1}$ can cause high percentages of dwarfed fruit in some years (Rogers and Williams, 1977). Carbaryl plus lower rates of NAA (2 to $5 \mathrm{mg} \cdot \mathrm{liter}^{-1}$ ) gave excellent thinning in some years, but caused serious overthinning and/or dwarfed fruit in others (Rogers and Williams, 1977). Combinations of ethephon and carbaryl have been used under a state label in North Carolina and Virginia, but no federal label exists. Ethephon has been considered very doseand temperature-dependent; however, in Virginia, the ethephon + carbaryl combination has given good thinning in most tests (Byers et al., 1990a). Oxamyl (a systemic carbamate) at its highest insecticidal rate has given mild thinning similar to that of carbaryl (Byers et al., 1982), but no federal label exists for its use as a thinner. Carbaryl increases mite populations, probably due to the killing of mite predators. Oxamyl used as a thinner did not affect mite populations (Byers et al., 1982). Preliminary studies showed that the addition of superior oil $(2.5,5$, and $10 \mathrm{mg}$-liter') to carbaryl reduced mite populations (Horsburgh and Cobb, unpublished data). Terbacil, a photosynthetic inhibitor, applied to the foliage at very low rates, or artificially shading (2\%) the tree for 2 days, caused thinning (Byers et al., 1990a, 1990b). However, since terbacil is a very persistent herbicide, overthinning and injury were more serious than with other thinning chemicals in one test (Byers et al., 1990a)

Since certain pesticides labeled for use on apples reduce photosynthesis of apple leaves by $20 \%$ to $30 \%$ in multiple applications in the laboratory [superior oil (Ayers and Barden, 1975; Ferree and Hall, 1975; Ferree et al., 1976; Wood and Payne, 1984), ethion (Heinicke and Foott, 1966), dicofol (Sharma et al., 1977), fenvalerate (Wood and Payne, 1984), diazinon

Table 1. Effect of various chemicals on 'Campbell Redchief Delicious' apple fruit set and photosynthesis (1987).

\begin{tabular}{|c|c|c|c|c|c|c|c|c|}
\hline & & $\begin{array}{c}\text { Active } \\
\text { ingredient }\end{array}$ & $\begin{array}{l}\text { Fruit } / \mathrm{cm}^{2} \text { of limb } \\
\text { cross-sectional area }\end{array}$ & $\begin{array}{r}\text { Photo } \\
\text { (mg CO } \\
\text { days afte }\end{array}$ & $\begin{array}{l}\text { thesis } \\
\text { n per } h \text {, } \\
\text { olication) }\end{array}$ & Spur shoot & $\begin{array}{l}\text { No. spurs/cm } \\
\text { length of }\end{array}$ & $\begin{array}{l}\text { Return bloom } \\
1988 \text { ( } \% \text { spurs }\end{array}$ \\
\hline Treat & tment ${ }^{x, y}$ & (per liter) & (+52 days $A F B)$ & +1 & +5 & length $(\mathrm{cm})$ & shoot & flowering) \\
\hline 1) & Control & & $2.59 \mathrm{a}^{\mathrm{x}}$ & $21 a$ & $24 \mathrm{a}$ & $2.47 \mathrm{c}$ & $0.29 \mathrm{a}$ & $9.2 \mathrm{c}$ \\
\hline 2) & Hand-thinncd & & & & & & & \\
\hline & $(+52$ days $\mathrm{AFB})$ & & $1.84 \mathrm{ab}$ & & & $2.64 \mathrm{c}$ & $0.27 \mathrm{a}$ & $9.8 \mathrm{c}$ \\
\hline 3) & Oil & $2.5 \mathrm{ml}$ & $2.56 \mathrm{a}$ & & & & & 24.3 \\
\hline 4) & Oil & $10.0 \mathrm{ml}$ & $2.45 \mathrm{a}$ & $21 \mathrm{a}$ & $25 \mathrm{a}$ & & & $7.2 \mathrm{c}$ \\
\hline 5) & Carbaryl $50 \mathrm{WP}$ & $900 \mathrm{mg}$ & $0.95 \mathrm{~cd}$ & & & & & $76.7 \mathrm{a}$ \\
\hline 6) & $\begin{array}{l}\text { Carbaryl } 50 \mathrm{WP} \\
+ \text { oil }\end{array}$ & $\begin{array}{c}900 \mathrm{mg} \\
2.5 \mathrm{ml}\end{array}$ & $0.90 \mathrm{~cd}$ & & & $2.92 \mathrm{c}$ & $0.30 \mathrm{a}$ & $69.2 \mathrm{a}$ \\
\hline 7) & $\begin{array}{l}\text { Carbaryl } 50 \mathrm{WP} \\
+ \text { oil }\end{array}$ & $\begin{array}{l}900 \mathrm{mg} \\
10.0 \mathrm{ml}\end{array}$ & $0.78 \mathrm{de}$ & & & & & $49.2 \mathrm{ab}$ \\
\hline 8) & $\begin{array}{l}\text { Carbaryl } 50 \text { WP } \\
+ \text { Ethion } 4 \text { EC }\end{array}$ & $\begin{array}{l}900 \mathrm{mg} \\
1160 \mathrm{mg}\end{array}$ & $0.58 \mathrm{e}$ & & & $3.97 \mathrm{c}$ & $0.28 \mathrm{a}$ & $72.5 \mathrm{a}$ \\
\hline 9) & $\begin{array}{l}\text { Carbaryl } 50 \mathrm{WP} \\
\text { + Ethion } 4 \mathrm{EC} \\
\text { + oil }\end{array}$ & $\begin{array}{c}900 \mathrm{mg} \\
1160 \mathrm{mg} \\
10.0 \mathrm{ml}\end{array}$ & $0.56 \mathrm{e}$ & $21 \mathrm{a}$ & $24 a$ & & & $81.3 \mathrm{a}$ \\
\hline 10) & $\begin{array}{l}\text { Carbaryl } 50 \mathrm{WP} \\
\text { + oil } \\
\text { + Ethion } 4 \text { EC } \\
\text { + Vapor Gard }\end{array}$ & $\begin{array}{c}900 \mathrm{mg} \\
10.0 \mathrm{ml} \\
1160 \mathrm{mg} \\
20.0 \mathrm{ml}\end{array}$ & $0.40 \mathrm{e}$ & & & & & $59.2 \mathrm{ab}$ \\
\hline 11) & $\begin{array}{l}\text { Carbaryl } 50 \mathrm{WP} \\
+ \text { Diazinon 50WP }\end{array}$ & $\begin{array}{l}900 \mathrm{mg} \\
1250 \mathrm{mg}\end{array}$ & $0.69 \mathrm{e}$ & & & & & $77.5 \mathrm{a}$ \\
\hline 12) & $\begin{array}{l}\text { Terbacil } 80 \mathrm{WP} \\
+\mathrm{X}-77\end{array}$ & $\begin{array}{l}50 \mathrm{mg} \\
1.25 \mathrm{ml}\end{array}$ & $0.28 \mathrm{e}$ & $1 \mathrm{~b}$ & $13 \mathrm{~b}$ & & & $63.3 \mathrm{a}$ \\
\hline 13) & $\begin{array}{l}\text { 6-BA } \\
+\mathrm{X}-77\end{array}$ & $\begin{array}{l}50 \mathrm{mg} \\
1.25 \mathrm{ml}\end{array}$ & $1.64 \mathrm{bc}$ & & & $3.66 \mathrm{c}$ & $0.32 \mathrm{a}$ & $25.8 \mathrm{c}$ \\
\hline 14) & $\begin{array}{l}6-\mathrm{BA} \\
+\mathrm{X}-77\end{array}$ & $\begin{array}{l}200 \mathrm{mg} \\
1.25 \mathrm{ml}\end{array}$ & $0.20 \mathrm{e}$ & & & $9.95 \mathrm{~b}$ & $0.31 \mathrm{a}$ & $32.5 \mathrm{bc}$ \\
\hline 15) & $\begin{array}{l}\text { 6-BA } \\
+ \text { oil }\end{array}$ & $\begin{array}{l}50 \mathrm{mg} \\
10.0 \mathrm{ml}\end{array}$ & $0.06 \mathrm{e}$ & & & $10.47 \mathrm{ab}$ & $0.30 \mathrm{a}$ & $11.3 \mathrm{c}$ \\
\hline 16) & $\begin{array}{l}\text { 6- }- \text { AA } \\
+ \text { Carbaryl } 50 \mathrm{WP} \\
+ \text { oil }\end{array}$ & $\begin{array}{l}200 \mathrm{mg} \\
900 \mathrm{mg} \\
10.0 \mathrm{ml}\end{array}$ & $0.01 \mathrm{e}$ & & & 12.712 & $0.29 \mathrm{a}$ & $31.7 \mathrm{bc}$ \\
\hline
\end{tabular}

Full bloom occurred 1 May 1987.

${ }^{y}$ Fruit size was $8.98 \pm 0.35 \mathrm{~mm}$ on 13 May 1987 (FB + 12 days $)$.

'Mean separation within columns by Duncan's multiple range test, 5\% level.

"Return bloom was a visual estimate of the percentage of spurs flowering at bloom. Data were transformed to arcsin of the square root of the percentage before analysis. 
(Heinicke and Foott, 1966), and other organic phosphates (Ayers and Barden, 1975; Ferree and Hall, 1978, Pickett et al., 1952)], combinations of these could potentiate thinning by carbaryl.

The general objective of this research was to identify combinations of chemicals that would give a range of thinning responses from no thinning to defruiting young spur 'Delicious' trees so that a grower could choose a combination to fit a particular thinning need. The specific objectives were to: 1) screen certain pesticides that inhibit photosynthesis for their potentiation of carbaryl for thinning, 2) evaluate 6BA and its combinations with carbaryl and/or 70-sec superior oil for thinning, 3) compare the $50 \mathrm{WP}$ and $4 \mathrm{~L}$ formulations of carbaryl, and 4) evaluate other chemicals as potential thinning agents.

\section{Materials and Methods}

Experiment 1. In 1987, 96 sixyear-old 'Campbell Redchief Delicious'/MM.111 trees were selected for uniform flowering at bloom and were blocked according to row and terrain into six blocks for the 16 treatments listed in Table 1. Chemicals were applied with a hand-held pressurized sprayer using $\approx 2.5$ liter/tree. Two limbs per tree were tagged near the trunk before treatment. At the point where limbs were tagged, limb circumference was measured. Fruit numbers per tree were recorded after fruit drop [+52 days after full bloom (AFB)] and expressed as fruit $/ \mathrm{cm}^{2}$ of $\mathrm{limb}$ cross-sectional area (LCSA) using methods described previously (Byers et al., 1990a, 1990b, 1991).

Net photosynthesis (Pn) was measured in the field with a portable ADC LCA-2 infrared CO, analyzer equipped with a Parkinson leafchamber (Analytical Development Co., Ltd., supplied by P.K. Morgan Instruments, Inc., 2 Dundee PK 'Level 1', Andover, Mass.) that exposed $6.25 \mathrm{~cm}^{2}$ of leaf to sunlight. Only bright, cloudless days were chosen for Pn measurements (Byers et al., 1990b). Measurements were recorded between 10:00 AM and 1:00 PM consecutively by block. Photosynthesis of three leaves on each of two trees for each treatment was measured 1 and 5 days after treatment $(+13$ and +17 days AFB).

The following spring, two 2-yearold scaffold limbs on each tree were selected for measuring spur numbers and spur lengths. In 1988, return bloom was estimated visually as the percentage of spurs flowering at full bloom for each tree.

Experiment 2. In 1988, 96 seven-year-old 'Campbell Redchief Delicious'/M.111 trees were selected for uniform flowering at bloom and were blocked according to row and terrain into six blocks for the 16 treatments listed in Table 2. Chemicals were applied and data collected as in Expt. 1, except fruit numbers per tree were recorded +49 days AFB.

Experiment 3. In 1989, 96 fiveyear-old 'Redspur Delicious'/M.26 trees were selected for uniform flowering and were blocked according to row and terrain into six blocks for the 15 treatments listed in Table 3. Chemicals were applied with a hand-held pressurized sprayer using $\approx 2$ liter/tree. Trees were tagged on the trunk before treatment. Fruit numbers per tree were recorded after fruit drop (+55 days AFB) and expressed as fruit $/ \mathrm{cm}^{2}$ of trunk cross-sectional area (TCSA) using methods described previously (Byers et al., 1990a, 1990b, 1991). Near harvest, a representative lo-fruit sample was harvested from each tree. For each fruit, fruit diameter was measured with a band sizer, red color was estimated visually as the percentage of the fruit surface showing red, and firmness of each fruit was measured

Table 2. Effect of parions chemicals on 'Campbell Redcbief Delicious'M.111 apple fruit set (1988).

\begin{tabular}{|c|c|c|}
\hline Treatment" & $\begin{array}{c}\text { Active } \\
\text { ingredient } \\
\text { (per liter) }\end{array}$ & $\begin{array}{c}\text { Fruit } / \mathrm{cm}^{2} \text { of limb } \\
\text { cross-sectional area } \\
\text { (+49 days AFB) }\end{array}$ \\
\hline
\end{tabular}
1) Control
$6.11 b^{x}$
2) Hand-thinned (+49 days $\mathrm{AHB})$
3) Carbaryl $50 \mathrm{WP}$
4) Carbaryl $50 \mathrm{WP}$ + oil
5) Carbaryl $50 \mathrm{WP}$ + oil
6) Carbaryl $50 \mathrm{WP}$ + Ethion 4 EC + oil
7) Carbaryl $50 \mathrm{WP}$ + Ethion 4 EC + oil $+\mathrm{CaCl}_{2}$
8) Carbaryl $50 \mathrm{WP}$ + ferbam $50 \mathrm{WP}$ + oil
9) Ferbam $50 \mathrm{WP}$
10) Carbaryl $50 \mathrm{WP}$ + oil
11) $6-\mathrm{BA}$ $+\mathrm{CaCl}_{2}$
12) $6-\mathrm{BA}$ + oil
13) 6-BA + Carbaryl 50 WP + oil
14) 6-BA + Carbaryl $50 \mathrm{WP}$ + oil
15) 6-BA + Carbaryl $50 \mathrm{WP}$ + Tween
16) 6-BA $+\mathrm{GA}_{4+7}$ (Promalin) $3.57 \mathrm{~cd}$ $3.09 \mathrm{c}-\mathrm{c}$ $2.07 \mathrm{ef}$
$1.41 \mathrm{f}-\mathrm{h}$
$1.48 \mathrm{f}-\mathrm{h}$
$1.43 \mathrm{f}-\mathrm{h}$
$0.46 \mathrm{hi}$
$900 \mathrm{mg}$
$12,550 \mathrm{mg}$
$10.0 \mathrm{ml}$
$12,550 \mathrm{mg}$
$900 \mathrm{mg}$
$10.0 \mathrm{ml}$
$10.0 \mathrm{~g}$
$50 \mathrm{mg}$
$50 \mathrm{mg}$
$10.0 \mathrm{ml}$
$50 \mathrm{mg}$
$900 \mathrm{mg}$
$10.0 \mathrm{ml}$
$100 \mathrm{mg}$
$900 \mathrm{mg}$
$10.0 \mathrm{ml}$
$50 \mathrm{mg}$
$900 \mathrm{mg}$
$1.3 \mathrm{ml}$
$200 \mathrm{mg}$
Full bloom occurred 22 Apr. 1988.
Fruit size was 11 mm on 13 May 1988 (FB +21 days).
*Mean separation within columns by Duncan's multiple range test, $5 \%$ Level. 


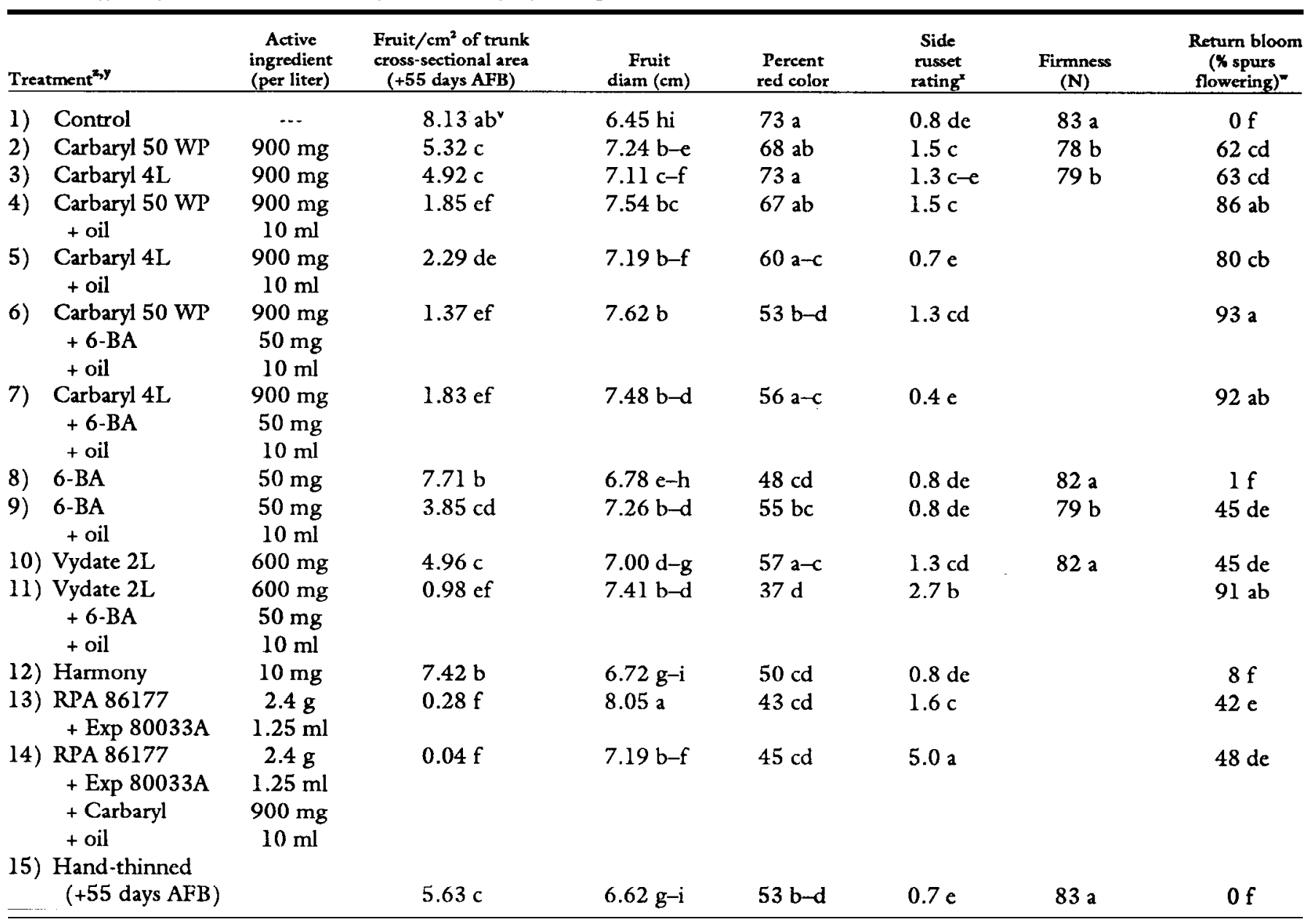

${ }^{\bar{z}}$ Full bloom occured 25 Apr. 1989.

Treatment were applied 25 May 1989-30 days AFB, when fruit diameter was $15 \mathrm{~mm}$.

Side russett rating: $0=$ lenticel enlargement; 2 = lenticel enlargement and some russet between lenticels; 3 = lenticel enlargement and slightly raised to touch, moderate to heavy russet between lenticels; $4=$ lenticel enlargement and moderately raised to torch and moderate to heavy russet between lenticels; 5 = lenticel enlargement and heavily raised to touch and heavy russet bctween lenticels.

${ }^{w}$ Return bloom was a visual estimate of the percentage of spurs flowering at bloom. Data were transformed to arcsin of the square root of the percentage before analysis.

"Mean separation within columns by Duncan's multiple range test, $5 \%$ levcl.

on two sides with a McCormick penetrometer (Yakima, Wash.) with a 11.1$\mathrm{mm}$ tip. Fruit finish was rated from 0 to 5 as follows: $0=$ no lenticel enlargement; 1 = lenticel enlargement; 2 $=$ lenticel enlargement and some russet between lenticels; 3 = lenticel enlargement and slightly raised to touch, moderate to heavy russet between lenticels; 4 = lenticel enlargement and moderately raised to touch and moderate to heavy russet between lenticels; $5=$ lenticel enlargement and heavily raised to touch and heavy russet between lenticels. In 1990, return bloom was estimated visually as the percentage of spurs flowering at full bloom for each tree.

Experiment 4. In 1989, 60 fiveyear-old 'Golden Delicious'/M.26 trees trained to a three-wire trellis were se- lected for uniform flowering and were blocked according to row and terrain into six blocks for the 10 treatments listed in Table 4. Trees were tagged, chemicals and/or artificial shade were applied, and data taken as in Expt. 3, except fruit numbers were taken +50 days AFB. Fruit finish was rated from 0 to 5 as follows: $0=$ no lenticel enlargement; 1 = small lenticel enlargement; 2 $=$ lenticels rough and raised to touch; 3 = some russet between lenticels; $4=$ considerable russet between lenticels; $5=$ severe russet.

At harvest, the numbers of viable and aborted seeds were counted in each fruit of the 10-fruit sample from each tree. In 1990, return bloom was estimated visually as the percentage of spurs flowering at full bloom for each tree.

Experiment 5. In 1989, 42 five- year-old 'Stayman'/M.9 trees were selected for uniform flowering and were blocked according to row and terrain into six blocks for the seven treatments listed in Table 5. Trees were tagged, chemicals and/or artificial shade were applied, and data taken as in Expt. 3, except fruit numbers per tree were taken +51 days AFB.

At harvest, the number of viable and aborted seeds were counted in each fruit of the 10-fruit sample from each tree. In 1990, return bloom was estimated visually as the percentage of spurs flowering at full bloom for each tree.

Experiment 6. In 1989, eight 14year-old 'Golden Delicious'/M.9 trees were selected for uniform crop load. At 13 days AFB, four limbs on each tree were tagged and the number of 
fruit on each limb was recorded. Two applications of the antitranspirant RPA 86177 treatments listed in Table 6 were applied to one limb on each tree and compared to an untreated control. The number of fruit on each limb was recounted 72 days AFB. Fruit russet was evaluated as described previously in Expt. 4.

Experiment 7. In 1990, 102 fiveyear-old 'Nured Delicious'/M.7 trees were selected for uniform flowering and were blocked according to row and terrain into six blocks for the 17 treatments listed in Table 7. Trees were tagged, chemicals were applied, and data taken as in Expt. 3, except fruit numbers per tree were taken after fruit drop +53 days AFB. Photosynthesis was measured as described in Expt. 1.

In 1991, return bloom was esti- mated visually as 1) the percentage of spurs (2 years old and older) flowering at full bloom and 2) the percentage of nodes flowering on 1-year-old wood.

\section{Results and Discussion}

Natural fruit set and chemical thinning results may be quite variable from year to year. For this reason, a control, a hand-thinned treatment, carbaryl $50 \mathrm{WP}$, and carbaryl $50 \mathrm{WP}+$

Table 4. Effect of artificial shade and chemical thinning materials on 'Golden Delicious' /M.26 fruit set (1989).

\begin{tabular}{|c|c|c|c|c|c|c|c|c|c|c|c|c|c|}
\hline \multirow[b]{2}{*}{ Treatment" } & \multirow{2}{*}{$\begin{array}{l}\text { Active } \\
\text { ingredient } \\
\text { (per liter) } \\
\end{array}$} & \multirow{2}{*}{$\begin{array}{c}\text { Fruit } / \mathrm{cm}^{2} \text { of trunk } \\
\text { cross-sectional } \\
\text { area } \\
(+50 \text { days AFB }) \\
\end{array}$} & \multirow{2}{*}{$\begin{array}{l}\text { Russet } \\
\text { rating" }\end{array}$} & \multirow[b]{2}{*}{$\begin{array}{c}\text { Stem end } \\
\text { russet' }\end{array}$} & \multicolumn{4}{|c|}{ Percent U.S. Grade" } & \multirow{2}{*}{$\begin{array}{c}\text { No. } \\
\text { viable } \\
\text { seeds/ } \\
\text { fruit }\end{array}$} & \multirow{2}{*}{$\begin{array}{l}\text { Total } \\
\text { (viable + } \\
\text { aborted) } \\
\text { seeds/fruit }\end{array}$} & \multirow{2}{*}{$\begin{array}{l}\text { Percent } \\
\text { viable } \\
\text { seeds }\end{array}$} & \multirow{2}{*}{$\begin{array}{l}\text { Fruit } \\
\text { diam } \\
(\mathrm{cm})\end{array}$} & \multirow{2}{*}{$\begin{array}{r}\begin{array}{r}\text { Return } \\
\text { bloom } \\
\text { (\% spurs } \\
\text { flowering) }\end{array} \\
\end{array}$} \\
\hline & & & & & $\begin{array}{l}\text { Extra } \\
\text { fancy } \\
\end{array}$ & Fancy & $\begin{array}{c}\text { No. } \\
\text { I }\end{array}$ & Utility & & & & & \\
\hline 1) Control & & $8.65 \mathrm{a}^{\mathrm{x}}$ & $1.81 \mathrm{a}$ & $1.25 \mathrm{a}$ & 13 a & $69 \mathrm{a}$ & 17 a & 0 a & $5.4 \mathrm{a}$ & $5.7 \mathrm{a}$ & $94 \mathrm{a}$ & $7.52 \mathrm{~b}$ & $3 \mathrm{~d}$ \\
\hline 2) Shade (2 days) & & $3.22 \mathrm{de}$ & & & & & & & $2.5 \mathrm{~b}$ & $6.2 \mathrm{a}$ & $41 \mathrm{~b}$ & $8.08 \mathrm{a}$ & $84 \mathrm{~b}$ \\
\hline 3) Shade (3 days) & & $1.01 \mathrm{f}$ & & & & & & & & & & & $80 \mathrm{~b}$ \\
\hline $\begin{array}{l}\text { 4) NAA } \\
+ \text { Tween } 20\end{array}$ & $\begin{array}{l}10 \mathrm{mg} \\
1.25 \mathrm{ml}\end{array}$ & $4.36 \mathrm{~cd}$ & $1.87 \mathrm{a}$ & $1.39 \mathrm{a}$ & $7 \mathrm{a}$ & $70 \mathrm{a}$ & $22 \mathrm{a}$ & $0 \mathrm{a}$ & $5.1 \mathrm{a}$ & $6.0 \mathrm{a}$ & $84 \mathrm{a}$ & $7.98 \mathrm{a}$ & $43 c$ \\
\hline $\begin{array}{l}\text { 5) NAA } \\
+ \text { Tween } 20 \\
+ \text { shade }(2 \text { days })\end{array}$ & $\begin{array}{c}10 \mathrm{mg} \\
1.25 \mathrm{ml}\end{array}$ & $0.75 \mathrm{f}$ & & & & & & & & & & & $83 \mathrm{~b}$ \\
\hline 6) Carbaryl $50 \mathrm{WP}$ & $900 \mathrm{mg}$ & $5.50 \mathrm{~b}$ & $1.73 \mathrm{a}$ & $1.22 \mathrm{a}$ & $12 \mathrm{a}$ & $74 a$ & $12 \mathrm{a}$ & $1 \mathrm{a}$ & & & & & $95 \mathrm{ab}$ \\
\hline $\begin{array}{l}\text { 7) Carbaryl } 50 \mathrm{WP} \\
+ \text { shade ( } 2 \text { days })\end{array}$ & $900 \mathrm{mg}$ & $2.14 \mathrm{ef}$ & & & & & & & & & & & $100 \mathrm{a}$ \\
\hline 8) Carbaryl 4I. & $900 \mathrm{mg}$ & $4.99 \mathrm{bc}$ & $1.85 \mathrm{a}$ & $1.47 \mathrm{a}$ & $10 \mathrm{a}$ & $68 \mathrm{a}$ & $22 \mathrm{a}$ & $0 \mathrm{a}$ & $5.1 \mathrm{a}$ & $5.8 \mathrm{a}$ & $86 a$ & $8.00 \mathrm{a}$ & $95 \mathrm{ab}$ \\
\hline $\begin{array}{l}\text { 9) Carbaryl 4L } \\
+ \text { shade ( } 2 \text { days) }\end{array}$ & $900 \mathrm{mg}$ & $1.50 \mathrm{f}$ & & & & & & & & & & & $100 \mathrm{a}$ \\
\hline $\begin{array}{l}\text { 10) Hand-thinned } \\
(+50 \text { days AFB })\end{array}$ & & $6.35 b$ & $1.74 \mathrm{a}$ & $1.15 \mathrm{a}$ & $11 \mathbf{a}$ & $74 \mathrm{a}$ & $14 \mathrm{a}$ & $0 \mathrm{a}$ & & & & & $2 \mathrm{~d}$ \\
\hline
\end{tabular}

Full bloom occurred on 27 Apr. 1989.

'Spray and shade treatments began 24 May 1989-27 days AFB when fruit diameter was $15 \mathrm{~mm}$.

'Mean separation within columns by Duncan's multiple range test, $5 \%$ level,

"Rating scale: $0=$ no lenticel development; 1 = small lenticel enlargement; 2 = lenticel rough and raised to touch; 3 = some russet between lenticels,

4 = considerable russeting other than lenticels; 5 = severe russet.

Rating scale: $0=$ no stem end russet; 5 = severe stem end russet.

"U.S. grade standards were equivalent to russet scale: extra fancy $=0$ to $1.49 ;$ fancy $=1.50$ to $2.49 ;$ U.S. no. $1=2.50$ to $3.49 ;$ utility $=3.5$ to 5.50

'Return bloom was a visual estimate of the percentage of spurs flowering at bloom. Data were transferred to arcsin of the square root of the percentage before analysis

Table 5. Effect of artificial shade and chemical thinning material on 'Stayman/M.9 fruit set (1989).

\begin{tabular}{|c|c|c|c|c|c|c|c|c|}
\hline Treatment" & $\begin{array}{l}\text { Active } \\
\text { ingredient } \\
\text { (per liter) }\end{array}$ & $\begin{array}{c}\text { Fruit } / \mathrm{cm}^{2} \text { of trunk } \\
\text { cross-sectional area } \\
(+51 \text { days AFB) }\end{array}$ & $\begin{array}{c}\text { Side } \\
\text { russet } \\
\text { rating }\end{array}$ & $\begin{array}{l}\text { No. viable } \\
\text { seeds/fruit }\end{array}$ & $\begin{array}{c}\text { Total } \\
\begin{array}{c}\text { (viable }+ \text { aborted) } \\
\text { seeds } / \text { fruit }\end{array}\end{array}$ & $\begin{array}{c}\begin{array}{c}\text { Percent viable } \\
\text { seeds/ } \\
\text { fruit }\end{array} \\
\end{array}$ & $\begin{array}{l}\text { Fruit } \\
\text { diam } \\
(\mathrm{cm}) \\
\end{array}$ & $\begin{array}{c}\text { Return bloom } \\
\text { (\% spurs } \\
\text { flowering) } \\
\end{array}$ \\
\hline \multicolumn{2}{|l|}{ 1) Control } & $5.64 \mathrm{a}^{\mathrm{w}}$ & $1.17 \mathrm{~b}$ & $5.6 \mathrm{a}$ & $5.8 \mathrm{a}$ & 97 a & $7.70 \mathrm{c}$ & $51 \mathrm{c}$ \\
\hline \multicolumn{2}{|l|}{ 2) Shade (2 days) } & $0.03 \mathrm{~d}$ & & & & & & $97 \mathrm{a}$ \\
\hline \multicolumn{2}{|l|}{ 3) Shade (3 days) } & $0.01 \mathrm{~d}$ & & & & & & $84 \mathrm{ab}$ \\
\hline \multirow{2}{*}{$\begin{array}{l}\text { 4) NAA } \\
+ \text { Tween } 20\end{array}$} & $10 \mathrm{mg}$ & $1.62 \mathrm{c}$ & $1.65 \mathrm{a}$ & $5.5 \mathrm{a}$ & $6.0 \mathrm{a}$ & 92 a & $8.43 \mathrm{ab}$ & $88 \mathrm{ab}$ \\
\hline & $1.25 \mathrm{ml}$ & & & & & & & \\
\hline 5) Carbaryl $50 \mathrm{WP}$ & $900 \mathrm{mg}$ & $1.64 \mathrm{c}$ & $1.75 \mathrm{a}$ & $5.6 \mathrm{a}$ & $6.1 \mathrm{a}$ & 92 a & $8.38 \mathrm{ab}$ & 95 a \\
\hline 6) Carbaryl 4L & $900 \mathrm{mg}$ & $1.55 \mathrm{c}$ & $1.68 \mathrm{a}$ & $5.4 \mathrm{a}$ & $5.8 \mathrm{a}$ & 93 a & $8.59 \mathrm{a}$ & 95 a \\
\hline 7) Hand-thinned ( & days $A F B$ ) & $4.16 \mathrm{~b}$ & $1.32 \mathrm{~b}$ & 5.9 a & $6.4 \mathrm{a}$ & $94 a$ & $8.26 \mathrm{~b}$ & $79 \mathrm{~b}$ \\
\hline
\end{tabular}

Full bloom occurred on 25 Apr. 1989.

'Spray and shade treatments began 24 May 1989 - 29 days AFB when fruit diameter was $14 \mathrm{~mm}$.

Side russet rating: $0=$ lenticel enlargement; $2=$ lenticel enlargement and some russet between lenticel; $3=$ lenticel enlargement and slightly raised to touch, moderate to heavy russet between lenticels; $4=$ lenticel enlargement and moderately raised to torch and moderate to heavy russet between lenticels; 5 = lenticel enlargement and heavily raised to touch and heavy russet between lenticels.

"Mean separation within columns by Duncan+ multiple range test, $5 \%$ level.

"Return bloom was a visual estimate of the percentage of spurs flowering at bloom. Data were transformed to arcsin of the square root of the percentage before analysis. 
'Table 6. Effect of parious cbemicals on musset development of 'Golden Delicious' apple fruit (1989).

\begin{tabular}{|c|c|c|c|c|c|c|c|c|c|}
\hline \multirow[b]{2}{*}{ Treatment } & \multirow[b]{2}{*}{$\begin{array}{c}\text { Rate } \\
\text { (per liter) }\end{array}$} & \multirow[b]{2}{*}{$\begin{array}{l}\text { Application } \\
\text { (days AFB) }\end{array}$} & \multirow[b]{2}{*}{$\begin{array}{l}\text { Russet } \\
\text { rating" }\end{array}$} & \multirow[b]{2}{*}{$\begin{array}{l}\text { Stem end } \\
\text { russet }\end{array}$} & \multicolumn{4}{|c|}{ Percent U.S. Grade } & \multirow[b]{2}{*}{$\begin{array}{c}\text { Percent fruit } \\
\text { set }\end{array}$} \\
\hline & & & & & $\begin{array}{l}\text { Extra } \\
\text { fancy }\end{array}$ & Fancy & No. 1 & Utility & \\
\hline 1) Control & & & $3.08 b^{w}$ & $2.95 \mathrm{~b}$ & $0 \mathrm{a}$ & $10 a$ & $55 \mathrm{bc}$ & $35 a b$ & 52 a \\
\hline 2) RPA 86177 & $2400 \mathrm{mg}$ & 13,20 & $2.95 \mathrm{~b}$ & $3.05 \mathrm{~b}$ & $0 \mathrm{a}$ & $7 \mathrm{a}$ & $69 \mathrm{ab}$ & $24 \mathrm{bc}$ & $43 a$ \\
\hline 3) RPA 86177 & $600 \mathrm{mg}$ & 13,20 & $3.03 \mathrm{~b}$ & $2.90 \mathrm{~b}$ & $0 \mathrm{a}$ & $3 a$ & $78 a$ & $19 c$ & 51 a \\
\hline 4) RPA 86177 & $2400 \mathrm{mg}$ & 13,20 & $3.39 \mathrm{a}$ & $3.33 \mathrm{a}$ & $0 \mathrm{a}$ & $0 \mathrm{a}$ & $45 \mathrm{c}$ & 55 a & $9 \mathrm{~b}$ \\
\hline $\begin{array}{l}+ \text { surfactant } \\
(\operatorname{Exp} 80033 \mathrm{~A})\end{array}$ & $1.25 \mathrm{ml}$ & & & & & & & & \\
\hline
\end{tabular}

"Rating scale: $0=$ no lenticel depelopment; 1 = small lenticel enlargement; $2=$ lenticels rough and raised to touch; $3=$ some russet between lenticels; $4=$ considerable russetting other than lenticels; $5=$ severe russet.

Rating scale: $0=$ no stem end russet; $5=$ sepere stem end russet.

${ }^{*}$ U.S. grade standards were equipalent to russet scale: extra fancy $=0$ to 1.49 ; fancy $=1.50$ to $2.49 ;$ U.S. No. $1=2.50$ to $3.49 ;$ utility $=3.5$ to 5.0 .

"Mean separation within columns by Duncan's multiple range test, $5 \%$ level.

superior oil was included in most of the experiments on spur 'Red Delicious' (Tables 1-3 and 7). For example, in 1987, natural fruit set was poor and carbaryl overthinned in relation to the control (Table 1), but in 1988 (Table 2), 1989 (Table 3), and 1990 (Table 7), fruit set was good and carbaryl was less effective as a thinner. The data from several years indicate the superior oil usually increased the effectiveness of carbaryl, 6-BA, or other chemicals (RPA 86117) better than surfactants (Tables 2, 3, and 7). The growth regulators 6-BA and ethephon appear to be very powerful, rate-dependent chemical thinners (Tables 13 and 7) that, when used in combination with carbaryl + oil, might be used to thin very difficult-to-thin cultivars, or spur strains of 'Red Delicious'.

Since previous work has shown the great influence of low light on fruit abscission (Byers et al., 1990a, 1990b), several treatments were included to demonstrate the potential use of photosynthetic inhibition as a mode of action alone or in combination with other thinners such as terbacil (Table 1), ferbam (Table 2), RPA 86117 (Tables 3, 6, and 7), and shading (Tables 4-7). However, it should be noted that photosynthetic inhibition is not required for a chemical thinner to induce fruit abscission.

The results of each experiment are discussed in detail below by experiment because each year's results may be different.

Experiment 1. The application of superior oil alone at 2.5 or $10 \mathrm{ml} \cdot \mathrm{liter}^{-1}$ (treatments 3 and 4) did not cause thinning (Table 1). The combinations of carbaryl $50 \mathrm{WP}+$ ethion or + diazinon appeared to increase the thinning (treatments 5, 8, and 11) compared to carbaryl alone. Superior oil did not appear to potentiate carbaryl 50 WP (treatments 6 and 7), as it does in most of our experiments. Terbacil $80 \mathrm{WP}+\mathrm{X}-77$ caused fruitthinning by inhibiting photosynthesis (treatment 12), as has been determined previously (Byers et al., 1990b). Superior oil or carbaryl + ethion + oil did not appear to cause photosynthetic inhibition, but the combination caused severe thinning. The $200 \mathrm{mg}$ 6-BA/ liter $+\mathrm{X}-77$ treatment was more effective than $50 \mathrm{mg} \cdot$ liter $^{-1}$ (treatments 13 and 14), and thus the thinning response was considered rate-dependent. Superior oil was more effective than X77 for potentiating 6-BA (treatments 13 and 15). The combinations of 200 mg 6-BA/liter + X-77 (treatment 14), $50 \mathrm{mg}$ 6-BA/liter + oil (treatment 15), or $200 \mathrm{mg}$ 6-BA/liter + carbaryl + oil (treatment 16) were very effective for defruiting young trees and initiating side branches on annual growth. The $50 \mathrm{mg}$ 6-BA/liter + X-77 did not induce the initiation of side branches and was less effective as a thinner than $200 \mathrm{mg}$ 6-BA/liter + X-77 or $50 \mathrm{mg} \mathrm{6-}$ BA/liter + oil.

Treatments that thinned caused a better return bloom in 1988 . However, treatments that contained 6-BA did not appear to induce as good a return bloom as expected (treatments 13-16), considering that the trees were thinned more than other carbarylsprayed trees.

Experiment 2. The addition of $10 \mathrm{ml}$ superior oil/liter to carbaryl increased thinning (treatments 3 and 5); however, no further increase in thinning occurred with the addition of ethion, ethion $+\mathrm{CaCl}_{2}$, or $\mathrm{CaCl}_{2}$, (treatments 6 , 7, and 10) (Table 2). Ferbam (ferbam sprayed on a glass plate absorbed five times more photosynthetic active radiation than carbon black) caused fruit thinning (treatment 9) and appeared to increase the thinning by carbaryl + oil (treatments 4 and 8). The addition of superior oil to $50 \mathrm{mg}$ 6-BA/liter (treatments 11 and 12) increased the thinning, and the addition of carbaryl (treatment 13) to this combination increased thinning further. The addition of Tween 20 was as effective as oil for potentiating 6-BA (treatments 13 and 15). The combination of $100 \mathrm{mg}$ 6-BA/liter + carbaryl + oil nearly defruited these trees (treatment 14). Although the combination of $100 \mathrm{mg}$ 6-BA/liter + $100 \mathrm{mg}$ $\mathrm{GA}_{4+7} /$ liter was reported to cause thinning when applied in bloom (Stembridge and Morrell, 1972), $200 \mathrm{mg}$ 6-BA/liter $+200 \mathrm{mg} \mathrm{GA}_{4+7} /$ liter applied at this timing increased fruit set (treatment 16). Since $\mathrm{GA}_{4+7}$ is known to increase fruit set, the use of promalin as a thinner does not make much sense. Since an extreme drought in 1988 caused very poor return bloom in 1989, even on defruited trees, bloom data are not presented.

Experiment 3. Carbaryl $50 \mathrm{WP}$ and carbaryl $4 \mathrm{~L}$ thinned when used alone (treatments 2 and 3), when combined with superior oil (treatments 4 and 5), or when combined with 6BA + oil (treatments 6 and 7) (Table 3). Superior oil potentiated 6-BA (treatments 8 and 9). Oxamyl was potentiated by 6-BA + oil (treatments 10 and 11); however, this combination (treatment 11) reduced red color and increased opalescence. Oxamyl alone increased opalescence only slightly. The antitranspirant RPA 86117 + surfactant (Exp 890033A) caused overthinning with no injury to leaves or fruit (treatment 13). However, in Expt. 6 on 'Golden Delicious', RPA 86117 + surfactant (Exp 890033A) increased russet, which may have been a result of the surfactant. If 
carbaryl + oil were added to the RPA + surfactant, 'Redspur' trees were defruited and $\approx 30 \%$ of the leaves dropped (treatment 14). None of the other treatments caused fruit color or fruit finish differences. Fruit firmness did not appear to be affected by the material used and small differences were probably related to crop load.

Treatments that did not thin did not induce adequate return bloom for a crop in 1990 (treatments 1, 8, 12, and 15). Even though RPA (treatments 13 and 14) defruited trees, the return bloom was not as good as would be expected ( $42 \%$ and $48 \%$ spurs flowering) .

Experiment 4. Two days of artificial shade $(92 \%)$ caused more thinning than carbaryl $50 \mathrm{WP}$, carbaryl $4 \mathrm{~L}$, or $10 \mathrm{mg}$ NAA/liter + Tween 20 (treatments 2, 4, 6, and 8) (Table 4). The addition of 2 days of artificial shade to any of these chemical thinning combinations increased thinning. These data demonstrate the possible interaction between chemical thinning applications and environmentally induced "June drop," as reported previously (Byers et al., 1990a, 1990b, 1991). Fruit russet was not affected by the three chemical formulations. Shading induced seed abortion; however, neither NAA nor carbaryl had an effect on seed numbers. Fruit diameter was increased by shade-thinning of trees, and the reduced seed numbers caused by shading did not appear to affect fruit size. Return bloom of carbarylthinned trees (treatments 6-9) was superior to those thinned by NAA +Tween 20 (treatments 4 and 5).

Experiment 5. Two days of artificial shade caused more thinning of
'Stayman' trees than carbaryl $50 \mathrm{WP}$, carbaryl 4L, or $10 \mathrm{mg}$ NAA/liter + Tween (Table 5). Fruit russet was not different among the three chemical formulations, but all three had more russet than the control or the handthinned treatments. Fruit russet was probably a function of crop load and fruit size and not a direct effect of the chemicals. The number of viable seeds was not affected by the chemical thinners. There was an inadequate number of fruit on the shaded trees, as exhibited by a representative sample. Return bloom of 'Stayman' was affected by crop load, but not as much as were 'Golden Delicious' (Table 4) and 'Delicious' (Table 6).

Experiment 6. Two applications of RPA 86117 at $2400 \mathrm{mg} \cdot \mathrm{liter}^{-1}$ did not cause thinning or affect fruit russet; however, the combination of RPA

Table 7. Effect of various chemicals on fruit-thinning of 'Nured Delicious'/M.7 (1990).

\begin{tabular}{|c|c|c|c|c|c|c|c|c|c|c|}
\hline Treatment $^{2 y}$ & $\begin{array}{c}\text { Active } \\
\text { ingredient } \\
\text { (per liter) }\end{array}$ & $\begin{array}{c}\text { Fruit } / \mathrm{cm}^{2} \text { of } \\
\text { trunk cross- } \\
\text { sectional area } \\
(+51 \text { days AFB) } \\
\end{array}$ & $\begin{array}{l}\text { Photsynthesis } \\
\text { (mg CO } \mathrm{CO}_{2} / \mathrm{dm} \\
\text { per } \mathrm{h})+2 \text { days } \\
\text { after treatment }\end{array}$ & $\begin{array}{c}\text { Fruit } \\
\text { diam } \\
\text { (cm) } \\
24 \text { Aug. }\end{array}$ & $\begin{array}{c}\text { No. } \\
\text { viable } \\
\text { seeds/ } \\
\text { fruit }\end{array}$ & $\begin{array}{c}\text { Total } \\
\text { (viable + } \\
\text { aborted) } \\
\text { seeds / fruit }\end{array}$ & $\begin{array}{c}\text { Percent } \\
\text { viable } \\
\text { seeds/ } \\
\text { fruit } \\
\end{array}$ & $\begin{array}{l}\text { Russet } \\
\text { rating } \\
(0-5)^{x} \\
\end{array}$ & $\begin{array}{l}\text { Percent } \\
\text { spurs } \\
\text { flowering f } \\
\text { (19 Apr. } \\
1991) \text { (1 }\end{array}$ & $\begin{array}{l}\text { Percent } \\
\text { nodes } \\
\text { flowering(1- } \\
\text { year wood) } \\
19 \text { Apr. 1991) } \\
\end{array}$ \\
\hline 1) Control & & $8.06 \mathrm{ab}^{\mathrm{w}}$ & $17.4 \mathrm{a}$ & $6.62 \mathrm{e}$ & $2.27 \mathrm{def}$ & $3.40 c$ & $63.8 \mathrm{cdef}$ & $0.28 \mathrm{f}$ & $85 \mathrm{cde}$ & $5 e$ \\
\hline 2) Carbaryl $80 \mathrm{WP}$ & $900 \mathrm{mg}$ & $6.90 \mathrm{abc}$ & & $6.78 \mathrm{de}$ & $1.65 \mathrm{f}$ & $3.50 \mathrm{c}$ & $47.3 \mathrm{fgh}$ & $0.43 \mathrm{ef}$ & $96 \mathrm{abc}$ & $10 \mathrm{e}$ \\
\hline 3) Carbaryl 4L & $900 \mathrm{mg}$ & $5.95 \mathrm{bc}$ & & $6.75 \mathrm{de}$ & $1.92 \mathrm{ef}$ & $3.65 b c$ & $52.2 \mathrm{efg}$ & $0.59 \mathrm{def}$ & 90 bcde & $14 \mathrm{de}$ \\
\hline $\begin{array}{l}\text { 4) Carbaryl } 80 \mathrm{WP} \\
+ \text { oil }\end{array}$ & $\begin{array}{c}900 \mathrm{mg} \\
10 \mathrm{ml}\end{array}$ & $5.42 c$ & & $7.08 \mathrm{abc}$ & $1.37 \mathrm{f}$ & $3.96 \mathrm{abc}$ & $35.1 \mathrm{gh}$ & 0.71 cde & 95 abc & 17 cde \\
\hline $\begin{array}{l}\text { 5) Carbaryl 4L } \\
+ \text { oil }\end{array}$ & $\begin{array}{c}900 \mathrm{mg} \\
10 \mathrm{ml}\end{array}$ & $5.03 \mathrm{c}$ & & $6.95 \mathrm{bcd}$ & $1.5 \mathrm{f}$ & $4.73 \mathrm{a}$ & $31.7 \mathrm{~h}$ & $0.43 \mathrm{ef}$ & $93 \mathrm{bcd}$ & $30 \mathrm{bcd}$ \\
\hline $\begin{array}{l}\text { 6) Ethephon } \\
+ \text { Carbaryl } 80 \mathrm{WP}\end{array}$ & $\begin{array}{l}500 \mathrm{mg} \\
900 \mathrm{mg}\end{array}$ & $0.55 \mathrm{~d}$ & & $7.18 \mathrm{ab}$ & $2.72 \mathrm{cde}$ & $4.02 \mathrm{abc}$ & $71.8 \mathrm{bcd}$ & $0.50 \mathrm{def}$ & $100 \mathrm{a}$ & $38 \mathrm{bc}$ \\
\hline 7) Ethephon & $500 \mathrm{mg}$ & $2.36 \mathrm{~d}$ & & $7.18 \mathrm{ab}$ & $3.38 b c$ & $4.85 a$ & 70.7 bcd & 0.74 cde & $100 a$ & $33 \mathrm{bc}$ \\
\hline $\begin{array}{l}\text { 8) Ethephon (early } \\
\text { + oil } 16 \text { May) }\end{array}$ & $\begin{array}{r}500 \mathrm{mg} \\
10 \mathrm{ml}\end{array}$ & $1.09 \mathrm{~d}$ & & $7.28 \mathrm{a}$ & $3.37 b c$ & $4.4 \mathrm{abc}$ & $78.2 \mathrm{abc}$ & $0.67 \mathrm{cdc}$ & $100 \mathrm{a}$ & $49 \mathrm{~b}$ \\
\hline $\begin{array}{l}\text { 9) Ethephon (late } \\
\text { + oil } 5 \text { June) }\end{array}$ & $\begin{array}{r}1500 \mathrm{mg} \\
10 \mathrm{ml}\end{array}$ & $0.60 \mathrm{~d}$ & & $7.62 \mathrm{a}$ & $3.91 \mathrm{ab}$ & $4.28 \mathrm{abc}$ & $91.7 \mathrm{a}$ & $0.97 b c$ & $100 \mathrm{a}$ & $90 a$ \\
\hline 10) Carzol $92 \%$ & $275 \mathrm{mg}$ & $8.47 \mathrm{a}$ & & $6.68 \mathrm{de}$ & $3.53 \mathrm{abc}$ & $4.18 \mathrm{abc}$ & $83.8 \mathrm{ab}$ & 0.39 ef & $75 \mathrm{de}$ & $8 \mathrm{e}$ \\
\hline 11) Carzol $92 \%$ & $275 \mathrm{mg}$ & $7.60 \mathrm{ab}$ & & $6.68 \mathrm{de}$ & $2.60 \mathrm{cde}$ & $4.55 \mathrm{ab}$ & $57.4 \mathrm{def}$ & $0.56 \mathrm{def}$ & $73 \mathrm{e}$ & $5 \mathrm{c}$ \\
\hline $\begin{array}{l}+ \text { oil } \\
\text { 12) Oil }\end{array}$ & $\begin{array}{l}10 \mathrm{ml} \\
10 \mathrm{ml}\end{array}$ & $8.40 \mathrm{a}$ & & $6.62 \mathrm{e}$ & $3.13 \mathrm{bcd}$ & $4.72 \mathrm{a}$ & 67.1 bcde & $0.59 \mathrm{def}$ & 790 & $8 \mathrm{e}$ \\
\hline 13) RPA 86117 & $2.4 \mathrm{~g}$ & $7.78 \mathrm{ab}$ & $15.8 \mathrm{a}$ & $6.75 \mathrm{dc}$ & $3.42 \mathrm{bc}$ & $4.12 \mathrm{abc}$ & 82.2 abc & $0.48 \mathrm{def}$ & 83 bcde & $9 \mathrm{e}$ \\
\hline $\begin{array}{l}\text { 14) RPA } 86117 \\
\text { + surfactant } 80033 \mathrm{~A}\end{array}$ & $\begin{array}{r}2.4 \mathrm{~g} \\
\mathrm{~A} \quad 1.25 \mathrm{ml}\end{array}$ & $5.43 \mathrm{c}$ & $10.8 \mathrm{~b}$ & $6.80 \mathrm{cde}$ & $3.42 \mathrm{bc}$ & $4.30 \mathrm{abc}$ & $79.9 \mathrm{abc}$ & $0.81 \mathrm{~cd}$ & 88 bcde & 20 cde \\
\hline $\begin{array}{l}\text { 15) RPA } 86117 \\
+ \text { Tween } 20\end{array}$ & $\begin{array}{l}2.4 \mathrm{~g} \\
1.25 \mathrm{ml}\end{array}$ & $5.01 \mathrm{c}$ & $12.4 \mathrm{~b}$ & 6.93 bcde & $3.25 \mathrm{bc}$ & $4.05 \mathrm{abc}$ & $80.0 \mathrm{abc}$ & $1.14 \mathrm{~b}$ & 85 bcde & $13 \mathrm{de}$ \\
\hline $\begin{array}{l}\text { 16) RPA } 86117 \\
+ \text { oil }\end{array}$ & $\begin{array}{l}2.4 \mathrm{~g} \\
10 \mathrm{ml}\end{array}$ & $0.60 \mathrm{~d}$ & $10.0 \mathrm{~b}$ & $7.36 \mathrm{a}$ & $4.44 \mathrm{a}$ & $4.8 \mathrm{a}$ & $91.8 \mathrm{a}$ & $4.39 \mathrm{a}$ & 85 bcde & $29 \mathrm{bcd}$ \\
\hline $\begin{array}{l}\text { 17) Hand-thinned } \\
\text { (+ } 53 \text { days AFB) }\end{array}$ & & $5.31 \mathrm{c}$ & & $7.28 \mathrm{a}$ & $3.95 \mathrm{ab}$ & $4.25 \mathrm{abc}$ & $92.9 \mathrm{a}$ & $0.48 \mathrm{def}$ & $95 \mathrm{ab}$ & $19 \mathrm{cde}$ \\
\hline
\end{tabular}

${ }^{2}$ Full bloom occurred on 26 Apr. 1990.

${ }^{3}$ Treatments were applied 16 May - 20 days AFB when fruit diameter was $16 \mathrm{~mm} \pm 0.72 \mathrm{~mm}$, except treatment 9 , which was applied 5 June - 40 days AFB when fruit diameter was $30.5 \pm 0.63 \mathrm{~mm}$, which was $=10$ days after starch started accumulating in the fruit.

${ }^{x}$ Side russet rating: 1 = lenticel enlargement; 2 = lenticel enlargement and some russet between lenticel; 3 = lenticel enlargement and slightly raised to touch, moderate to heavy russet between lenticel; $4=$ lenticel enlargement and moderately raised to touch and moderate to heavy russet between lenticels; $5=$ lenticel enlargement and heavily raised to touch and heavy russet between lenticels.

"Mean separation within columns by Duncan's multiple range test, 5\% level. 
86117 + a surfactant (Exp 80033A) caused fruit thinning and increased russet. Further tests are required to determine if a change in the surfactant would eliminate the effect on fruit finish.

Experiment 7. Carbaryl $50 \mathrm{WP}$ and $4 \mathrm{~L}$ were equally effective for thinning alone (treatments 2 and 3) or when combined with superior oil (treatments 4 and 5) (Table 7). The number of viable seeds was not statistically different from the control. Carzol alone or with superior oil did not thin, nor did oil alone. At $500 \mathrm{mg}$ ethephon/liter + oil overthinned when fruits were $16 \mathrm{~mm}$; when fruits were $30 \mathrm{~mm}$ in diameter, which was about 10 days after starch had started to accumulate in the fruit, 1500 $\mathrm{mg}$ ethephon/liter + oil almost completely defruited trees. The antitranspirant RPA 86177 alone did not thin, but the addition of Exp 80033A surfactant or Tween 20 to the RPA 86117 increased thinning to the same extent. The addition of superior oil to RPA 86117, however, caused leaf injury, some defoliation, fruit russet, and defruiting of trees.

Photosynthesis was reduced by those RPA 86117 treatments that included a surfactant or superior oil (Table 7).

The return bloom on all trees was adequate for a full crop in 1991. Just $40 \%$ to $50 \%$ of the spurs flowering would have been adequate for a 111 crop. The check trees had $85 \%$ of the spurs flowering. Treatments that contained higher rates of ethephon and/or treatments that greatly thinned fruit from the trees caused more flower buds to develop on annual growth. These buds usually bloom later than spur flowers and may not be damaged by early frosts; however, they usually produce smaller fruit than those borne on spurs.

\section{Summary}

A range of thinning responses was achieved by combinations of certain thinners and adjuvants. Chemical thinning also increased return bloom.

The use ofsuperior oil as an adjuvant for carbaryl was effective 2 of 3 years, and it has the advantage of suppressing mite populations (Horsburgh and Cobb, unpublished data). However, oil increased russet in 'Golden Delicious' (unpublished data), but this was not a problem with 'Red Delicious'. Two formulations of carbaryl had similar thinning activity, whether applied alone or in combinations with artificial shade $(92 \%)$.

Our data suggest that 2 days of artificial shade (92\%) (equivalent to about 3 days of a typical cloudy period in the eastern United States) reduced viable seed numbers by $50 \%$, caused fruit thinning, and increased fruit size. Chemical thinners in these experiments did not affect seed numbers.

The amount of fruit removal desired from one or more chemical thinning sprays is a major management decision for fruit growers. In addition, the response from chemical thinning can be quite variable between years due to many factors (fruit set, cultivar or strain, rootstock, tree age, climate, site, culture, etc.). The experiments reported here were intended to give the grower a range of chemical thinning possibilities from no thinning to defruiting trees. Since a grower will likely make last-minute decisions to increase or decrease the amount of thinning desired (based on previous season's results, current season's weather, fruit set), the relative thinning level of various combinations of thinners or the addition of adjuvants in these experiments can be useful for estimating the relative contribution of them to fruit thinning.

\section{Literature Cited}

Ayers, J.C. and J.A. Barden. 1975. Net photosynthesis and darkrespiration of apple leaves as affected by pesticides. J. Amer. Soc. Hort. Sci. 100:24-28.

Byers, R.E. 1978. Chemical thinning of spur 'Golden Delicious' and 'Bisbee Delicious' with sevin and oxamyl. HortScience 13:5961.

Byers, R.E., J.A. Burden, and D.H. Carbaugh 199Oa. Thinning of spur 'Delicious' apples by shade, terbacil, carbaryl, and ethephon. J. Amer. Soc. Hort. Sci. 115:9-13.

Byers, R.E., J.A. Barden, R.F. Polomski, R.W. Young, and D.H. Carbaugh. 1990b. Apple thinning by photosynthetic inhibition. J. Amer. Soc. Hort. Sci. 115:14-19.

Byers, R.E., D.H. Carbaugh, C. N. Presley, and T.K Wolf 1991. The influence of low light levels on apple fruit abscission. J. Hort. Sci. (In press.)
Byers R.E., C.G. Lyons, and R.L. Horsburgh 1982. Comparisons of sevin and oxamyl for thinning apples. HortScience 17:777-778.

Ferree, D. C. and F. R. Hall. 1975. Influence of benomyl and oil on photosynthesis of apple leaves. HortScience 10:128-129.

Ferree, D. C. and F. R. Hall. 1978. Effects of growth regulators and multiple applications of pesticides on net photosynthesis and transpiration of greenhouse-grown apple trees. J. Amer. Soc. Hort. Sci. 103:61-64.

Ferree, D.C., F.R. Hall, and R.A.. Spotts. 1976. Influence of spray adjuvants and multiple applications of benomyl and oil on photosynthesis of apple leaves. HortScience 11:391-392.

Heinicke, D.R. and J.W. Foott. 1966. The effect of several phosphate insecticides on photosynthesis on Red Delicious apple leaves. Can. J. Plant Sci. 46:589-591.

Herrera-Aguirre, E. and C.R. Unrath 1980. Chemical thinning response of 'Delicious' ap-ples to volume of applied water. HortScience 15:43-44.

Pickett, W.F., A.S. Fish, Jr., and KS. Shaw. 1952. The influence of certain organic spray materials onphotosynthetic activity of peach and apple foliage. Proc. Amer. Soc. Hort. Sci. 60:111-114.

Rogers, B.L. and G.R. Williams. 1977. Chemical thinning of spur-type 'Delicious' apple trees. Virginia Fruit 65:23-28.

Sharma, D.P., D. C. Ferree, and F.O. Hartman. 1977. Multiple applications of dicofol and dodine sprays on net photosynthesis of apple leaves. HortScience 12: 154155.

Stembridge, G.E. and G. Morrell. 1972. Effect of gibberellins and 6-benzyladenine on the shape and fruit set of 'Delicious' apple. J. Amer. Soc. Hort. Sci. 97:465-467.

Wood, B. and J Payne. 1984. Influence of single applications ofinsecticide on net photosynthesis of pecan. HortScience 19:265266.

\section{Acknowledgements}

Appreciation to the following companies for chemicals: Rhone-Poulenc (carbaryl, ethephon, RPA 86117, surfactant-Exp. 80033A,), E. I duPont deNemours \& Company (oxamyl, terbacil, Harmony), Abbott Laboratories (6-BA, $\mathrm{GA}_{4+7}$ ), Drexel Chemical Co. (superior oil), CIBA-GEIGY (diazinon), FMC (ferbam, ethion), and for partial support by the Virginia and Pennsylvania State Horticultural Societies. 